\title{
Effect of School Yard Playgrounds on Development and School Attachment Levels of Children
}

\author{
Aybuke Dilbil", Zekiye Basaran \\ Department of Sport Management, Faculty of Sport Science, Kocaeli University, Turkey
}

Copyright $\bigcirc 2017$ by authors, all rights reserved. Authors agree that this article remains permanently open access under the terms of the Creative Commons Attribution License 4.0 International License

\begin{abstract}
The aim of this study is to examine the impact of playgrounds drawn in school yards on development and school attachment levels of the children. Sample of the study consisted of 319 students. 164 of them are female students while 155 are male students studying in the $3^{\text {rd }}$ and $4^{\text {th }}$ grades in Dr. Ferdi Koçel Elementary School, Yarbay Refik Cesur Elementary School and Saraybahce Elementary School located in the district of Izmit in Kocaeli. As for data collection tools, personal information questionnaire, school attachment scale (Savi, 2011) and school yard playgrounds questionnaire (Basaran, 2017) were employed. The data obtained from the questionnaires were analysed in the SPSS 18 package program and frequency and percentage distributions. Cronbach Alpha, Paired Sample T-Test and Independent T-Test were used $(p<0.05)$. At the end of the study, statistically significant differences were found between pretest/posttest scores of the school attachment scale, while no statistically significant difference was found in the playgrounds questionnaire. Differences were detected among some items of both scales and between pretest and grade in the playgrounds questionnaire. Diverse colourful drawings in the school yards of all elementary schools will be helpful in terms of development and school attachment in children.
\end{abstract}

Keywords Children, Playgrounds, School Attachment

\section{Introduction}

The first phase of human life begins with childhood. There is a special relationship between children and games, and children learn, socialize, grow and develop by playing (Akkülah, 2008). Games are the activities, which are conducted with physical and mental abilities in a specific time and place for a particular purpose in accordance with specific rules, and they entertain and improve social adaptation, intelligence and skills at the same time (Çoban \& Nacar, 2015).

Playing games is the most important occupation that children spend most of their time. They meet activity needs of the children, and through games, organs become stronger without wearing. They enhance attentiveness, courage and agility. They prepare children for social life by helping them adopt good behaviours and habits (Türkan, 2009). Thanks to games, children develop in terms of abstract abilities requiring mental capacity such as thinking, perceiving and mental planning (MEB $\left.{ }^{1}, 2016\right)$.

Children learn behaviours, information, skills etc. necessary for the life on their own through games. They develop and enhance insights into human relations, cooperation, speaking, obtaining information, gaining habits and experiences, roles in life via games (Çoban \& Nacar, 2015).

Playing games with friends enables a child to learn how to cooperate, help each other, share, live in communal life and make distribution of roles and division of labour. A child who socialises and comprehends the concepts of "I" and the "other" through games also learns how to undertake and give authority and responsibility through games. It has been observed that the children who grow by playing games become more socially active and outgoing when compared to those who grow without games (MEB, 2016).

Games stimulate all development areas of children and improve their senses and emotions as much as their skills. During games, children learn many things by experiencing themselves and become skilful (MEB, 2016). This process which starts in family continues in school. In particular, break times in schools are game times for children. These break times enable children to get rid of the impact of the previous lecture, to eliminate mental fatigue and to exercise and also have a significant function by ensuring active participation of children in the following lecture (Özdemir, 2011).

Games that children play with their friends at break times are as influential as lectures and teachers for the children to like the school environment. The games they play in the playground enable children to develop multiple

${ }^{1}$ Ministry of National Education 
skills and enhance their school attachment levels. Also, it has been demonstrated that playgrounds have positive impacts on the social, physical, emotional and cognitive development, mobility and creativity of children (Özdemir and Yilmaz, 2008). School yards are outdoor playgrounds, are indicators of public health, are socialisation environments for children and are tools for ensuring healthy development and increasing life quality (Algan and Uslu, 2009).

Games played in the open air ensure that children benefit from sunlight and fresh air and facilitate physical development. Games also ensure that toxic wastes are removed out of the body through sweating and children can use the accumulating energy (Külekçi, 2016). Through games, children get relaxed and rest. Social rules and realities are learned during games in the easiest and harmless manner. Lining up and waiting, respecting other people's rights, directing and being directed, being in harmony and cooperation with the others and undertaking his/her own responsibilities are the skills that can be developed via games. Also, the most effective way of developing such personal and social habits as self-confidence, self-control, prompt decision making, cooperating, integrity and discipline is games (MEB, 2016).

School yards should also be taken into consideration while playgrounds are being designed. School should have a planning to support mental and physical development, to shape the personality of the child and to increase the interest for the surrounding in addition to its instructive features. School and its surrounding should be planned to ensure that the children take pleasure in going to school (Çeliker et al., 2015; Türkan, 2009).

The impact of planning and design of school yards on the life of children have been examined in various studies (Şişman and Gültürk, 2011; Algan \& Uslu, 2009; Özdemir, 2011; Türkan, 2009). School yards are also effective in preventing childhood obesity. It has been determined that the children studying in schools with larger yards have lower body mass indices (BMI) (Özdemir and Yılmaz, 2008). Games and activities enhance creativeness, sense of responsibility, success, socialisation, physical, psycho-motor, emotional, social and language development, health, cognitive skills, perception-motor capability and coordination (Özdemir, 2011; MEB, 2016), contribute to their socialization, affect their studying skills in a positive manner and increase levels of attachment to school (Gömleksiz \& Özdeş, 2013).

Mengi (2011) defines attachment to school as feeling positive sentiments about the school, having positive connotations about education, attending the school, taking part in extracurricular social activities and spending extra time for school works. Savi (2011) states that there is a positive relationship between children's levels of attachment and their levels of social, emotional and academic adaptation, and most of the children lacking the feeling of attachment to school are not motivated to study while Cemalcilar (2010) argues that children with higher levels of school attachment have better relations with their teachers and friends, have higher levels of self-esteem and generally feel more satisfied about their lives (Bellici, 2015).

In line with the literature, it is known that games have impacts on all features of the children, their lives and whether they like school or not. However, since there is limited literature about this issue, this study aims to examine the impact of school playgrounds on the development and school attachment levels of children.

Problem statement: Colourful playgrounds drawn in school yards have impacts on the development and school attachment levels of the children.

Sub-problems:

- Colourful playgrounds drawn in school yards have impacts on development levels of children.

- Colourful playgrounds drawn in school yards have impacts on school attachment levels of children.

\section{Method}

\section{Research Method}

In this study, pretest posttest experimental model without control group was used.

\begin{tabular}{|c|c|c|c|}
\hline Groups & Pretest & Procedure & Posttest \\
\hline $\begin{array}{c}3^{\text {rd }} \text { and } 4^{\text {th }} \text { Grade } \\
\text { Students of } \\
\text { Schools }\end{array}$ & T1 & $\begin{array}{c}\text { Colourful playground } \\
\text { drawings in school } \\
\text { yards }\end{array}$ & T2 \\
\hline
\end{tabular}

This study was conducted between February and April 2017. To implement the study, playgrounds were drawn in the school yards for traditional Turkish child games in consideration of the structures of the school yards. These games included labyrinth, handkerchief grab, push-in-the-corner, tick-tack-toe, jacks, hopscotch (snake, ten, dragging, multiple), duck duck goose and compass.

\section{Population-sample Selection}

Study was carried out in the schools affiliated to the Ministry of National Education located in İzmit district of Kocaeli.

Schools where the study was conducted are:

1) Yarbay Refik Cesur Elementary School

2) Saray Bahçe Elementary School

3) Dr. Ferdi Koçel Elementary School

In these schools, $3^{\text {rd }}$ and $4^{\text {th }}$ grade students were included in the study. Sample consisted of 319 students in total, 164 of whom were female students and 155 of whom were male students.

Data Collection Tools: Personal information questionnaire, school attachment scale and playground game drawings questionnaire were used as data collection tools. 
Personal Information Questionnaire: This questionnaire was developed by the researcher and includes questions concerning the age, sex and grade information of the participants.

Playgrounds Questionnaire: This questionnaire was prepared by Basaran (2017) in consideration of the curriculum of the Ministry of National Education (MNE). For its validity test, support was received from academicians and teachers and administrators working in the schools affiliated to the MNE. For validity and reliability testing, the questionnaire was first applied to 60 primary school students (.843) and then 60 secondary school students (.841), and Cronbach Alpha reliability coefficients were found. After the questionnaire was finalized, it was applied on the sample. The questionnaire included 21 Likert type questions concerning the opinions of the children on the use of playgrounds.

School Attachment Scale (SAS): This scale (OBÖ-ÇE) was developed by Hill (2006) with the aim of evaluating the school attachment levels of the children and adolescents and consisted of items related to teachers, friends and school attachment. The original version of the scale was a 15-item Likert type scale consisting of five items in each dimension. This scale was adapted to the Turkish students by Savi (2011). Cronbach Alpha internal consistency coefficient of the scale was found as 0.84 while test-retest reliability coefficient was calculated as 0.85 for the whole scale. Final version of the scale consisted of 13 items. A high score from the scale demonstrates a high level of school attachment.

\section{Validity-Reliability Information:}

Reliability coefficients for this study are as follows:

- $\quad$ Playground Game Drawings: , 879

- School Attachment: , 887

\section{Data Collection}

Data were collected through questionnaires. Questionnaires were applied as pretest carried out before the study started and as posttest carried out after the study was completed. During preparation phase, approvals were received from the Kocaeli Provincial Directorate for National Education and Ethics Board of Kocaeli University. Study was conducted between February and April 2017.

Ministry of National Education: 22.03.2017 99332089605.01/ 3849261

KOU Ethics Board: 21.03.2017 / E-23600

\section{Data Analysis:}

Data obtained from the scales were analysed through SPSS 21 package program. Frequency and percentage calculations were made for the demographic attributes among the data. Paired Sample T Test was employed to determine the relationship between two dependent variables. Independent T-Test was carried out in order to determine the differences among age, sex and grades in pretest and posttest.

\section{Findings}

This section includes findings obtained at the end of the statistical analysis conducted on the data.

Table 1. Frequency and Percentage Distributions of the Demographic Information of the Participants

\begin{tabular}{|c|c|c|c|}
\hline \multicolumn{2}{|c|}{ Student } & $\mathbf{N}$ & $\%$ \\
\hline \multirow{2}{*}{ Sex } & Female & 164 & 51,4 \\
\hline & Male & 155 & 48,6 \\
\hline \multirow{2}{*}{ Age } & 8 & 118 & 36,9 \\
\hline & 9 & 201 & 63,1 \\
\hline \multirow{2}{*}{ Grade } & 3 & 118 & 37,0 \\
\hline & 4 & 201 & 63,0 \\
\hline
\end{tabular}

According to the distribution by sex given in Table 1, the ratio of female students is $51,4 \%$ while the ratio of male students is $48,6 \%$. When distribution by age is examined, it is seen that the ratio of those aged 8 is $8,8 \%$ while the ratio of those aged 9 is $37,6 \%$. Lastly, distribution by grades shows that the ratio of the $3^{\text {rd }}$ grades is $37 \%$ while the ratio of the $4^{\text {th }}$ grades is $63 \%$.

Table 2. Pretest and Posttest Comparisons of the School Attachment Scale (Paired Sample T-Test)

\begin{tabular}{|c|c|c|c|c|c|c|}
\hline & & $\mathbf{N}$ & Mean & S D & $\mathbf{t}$ & $\mathbf{p}$ \\
\hline \multirow{2}{*}{ School Attachment Scale } & Pretest & 319 & 55,63 & 10,64 & \multirow{2}{*}{$-1,829$} & \multirow{2}{*}{0,048} \\
\hline & Posttest & 319 & 59,92 & 7,87 & & \\
\hline
\end{tabular}

According to the results of the Paired Sample T Test on dependent groups, there is statistically significant difference among the pretest and posttest averages of the school attachment scale $(\mathrm{p}<0,05)$. 
Table 3. Pretest and Posttest Comparisons of the Items of the School Attachment Scale (Paired Sample T-Test)

\begin{tabular}{|c|c|c|c|c|c|c|}
\hline & & $\mathbf{N}$ & Mean & S D & $\mathbf{t}$ & $\mathbf{P}$ \\
\hline \multirow{2}{*}{ 1. I am proud of being in this school. } & Pretest & 319 & 4,05 & 0,84 & \multirow{2}{*}{0,776} & \multirow{2}{*}{$\mathbf{0 , 0 0 1 *}$} \\
\hline & Posttest & 319 & 4,38 & 0,83 & & \\
\hline \multirow{2}{*}{ 2. I am happy to be in this school. } & Pretest & 319 & 4,42 & 0,73 & \multirow{2}{*}{1,019} & \multirow{2}{*}{0,309} \\
\hline & Posttest & 319 & 4,36 & 0,85 & & \\
\hline \multirow{2}{*}{ 3. I feel myself safe in my school. } & Pretest & 319 & 4,26 & 0,95 & \multirow{2}{*}{0,134} & \multirow{2}{*}{0,894} \\
\hline & Posttest & 319 & 4,25 & 0,98 & & \\
\hline \multirow{2}{*}{ 4. I love my school. } & Pretest & 319 & 4,21 & 0,65 & \multirow{2}{*}{2,116} & \multirow{2}{*}{$\mathbf{0 , 0 3 5 *}$} \\
\hline & Posttest & 319 & 4,42 & 0,85 & & \\
\hline \multirow{2}{*}{ 5. I am proud of my friends in the school. } & Pretest & 319 & 4,34 & 0,86 & \multirow{2}{*}{$-0,167$} & \multirow{2}{*}{0,868} \\
\hline & Posttest & 319 & 4,35 & 0,88 & & \\
\hline \multirow{2}{*}{ 6. I have many friends that I like in my classroom. } & Pretest & 319 & 4,43 & 0,88 & \multirow{2}{*}{0,708} & \multirow{2}{*}{0,479} \\
\hline & Posttest & 319 & 4,38 & 0,84 & & \\
\hline \multirow{2}{*}{ 7. I have friends that I care in this school. } & Pretest & 319 & 4,16 & 0,92 & \multirow{2}{*}{$-0,477$} & \multirow{2}{*}{$0,044 *$} \\
\hline & Posttest & 319 & 4,40 & 0,84 & & \\
\hline \multirow{2}{*}{ 8. I have friends who care me in this school. } & Pretest & 319 & 4,20 & 0,93 & \multirow{2}{*}{$-0,772$} & \multirow{2}{*}{0,441} \\
\hline & Posttest & 319 & 4,26 & 1,00 & & \\
\hline \multirow{2}{*}{ 9. I love my friends in this school. } & Pretest & 319 & 4,50 & 0,71 & \multirow{2}{*}{1,278} & \multirow{2}{*}{0,202} \\
\hline & Posttest & 319 & 4,42 & 0,86 & & \\
\hline \multirow{2}{*}{ 10. Our teachers support their students a lot. } & Pretest & 319 & 4,50 & 0,76 & \multirow{2}{*}{1,484} & \multirow{2}{*}{0,138} \\
\hline & Posttest & 319 & 4,40 & 0,96 & & \\
\hline \multirow{2}{*}{ 11. I love my teachers. } & Pretest & 319 & 4,61 & 0,77 & \multirow{2}{*}{0,727} & 0468 \\
\hline & Posttest & 319 & 4,56 & 0,82 & & 0,400 \\
\hline 12. If I had poor performance in my courses, my teachers would deal & Pretest & 319 & 4,20 & 0,88 & $-0,242$ & $0,032 *$ \\
\hline with it. & Posttest & 319 & 4,31 & 0,98 & & \\
\hline 13 Our tegeherc know whether a student studies or not & Pretest & 319 & 4,57 & 0,69 & 1760 & 0070 \\
\hline 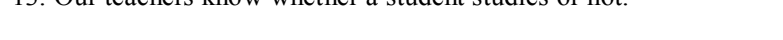 & Posttest & 319 & 4,47 & 0,85 & 1,700 & 年 \\
\hline
\end{tabular}

When Table 3 is examined, statistically significant differences were detected at the level of $p<0,05$ in the answers given by the students included in the study to the items of "I am proud of being in this school" $(0,001)$, "I like my school" $(0,035)$, I have friends that I care in this school" $(0,044)$, "If I had poor performance in my courses, my teachers would deal with it" $(0,032)$.

Table 4. Pretest and Posttest Comparisons of the Playgrounds Questionnaire (Paired Sample T-Test)

\begin{tabular}{|ccccccc|}
\hline & & N & Mean & S D & t & p \\
\hline \multirow{2}{*}{ Playgrounds } & Pretest & 319 & 61,9310 & 9,68603 & & \\
& Posttest & 319 & 62,5423 & 11,03955 &,- 731 &, 465 \\
\hline
\end{tabular}

According to the Table 4, there is not a statistically significant difference at the level of 0,05 between pretest and posttest results of the playgrounds scale $(, 465)$. However, mean values have increased. 
Table 5. Pretest and Posttest Comparisons of the Playgrounds Questionnaire Items (Paired Sample T Test)

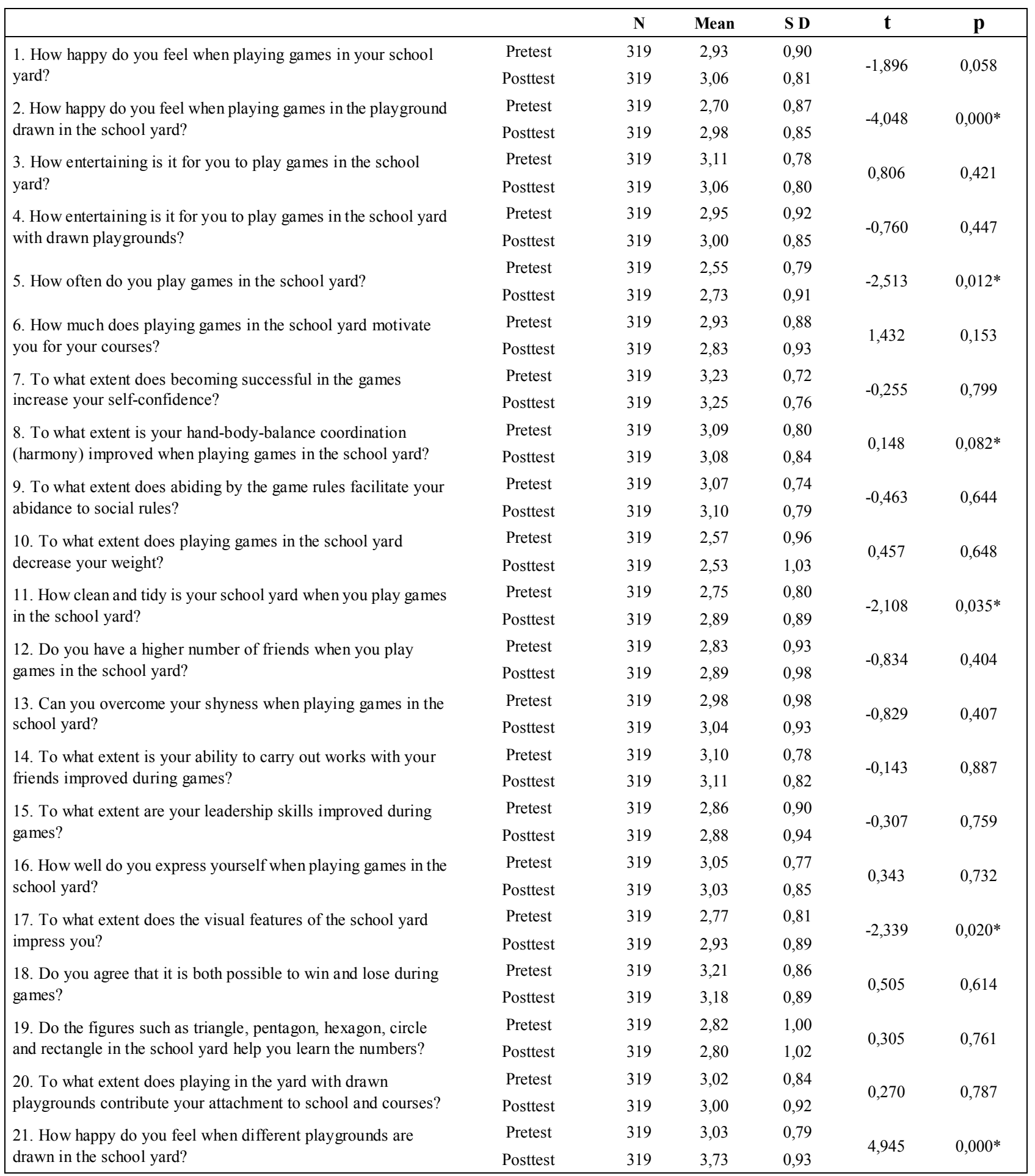

Table 6. Comparison of the Scores in the Playgrounds Questionnaire by Grades (Independent T-Test)

\begin{tabular}{|c|c|c|c|c|c|c|}
\hline Playgrounds & Grades & N & Mean & Std. Deviation & p \\
\hline \multirow{2}{*}{ Pretest results } & 3.Sinif & 118 & 63,6949 & 9,30078 & 2,513 \\
& 4.Sinif & 201 & 60,8955 & 9,78029 & 2,546 \\
\hline
\end{tabular}


When Table 5 is examined, statistically significant differences were detected in the answers given by the students included in the study to the items of How happy do you feel when playing games in the playground drawn in the school yard? $(0,000)$, How often do you play games in the school yard? $(0,012)$, How clean and tidy is your school yard when you play games in the school yard? $(0,035)$, To what extent does the visual features of the school yard impress you? $(0,020)$, How happy do you feel when different playgrounds are drawn in the school yard? $(0,000)$ at the level of $p<0.05$. No statistically significant difference was found in the other items.

According to the Table 6, a statistically significant different exists between the pretest results and grades $(, 012)$ in the playgrounds questionnaire at the level of 0,05 . This difference stems from the $3^{\text {rd }}$ grades.

\section{Conclusions, Discussion and Recommendations}

In the present study conducted to examine the effect of playgrounds drawn in the school yards on the development and school attachment levels of the children, all the students included in the sample are aged 8 and $9 ; 51,4 \%$ of them are female students while $48,6 \%$ of them are male students; and they are $3^{\text {rd }}(37 \%)$ and $4^{\text {th }}(63 \%)$ grade students.

Playgrounds of these children are school yards. Just like sports areas existing in school yards (basketball, volleyball, badminton etc.), the colourful drawings in school yards for such traditional Turkish games as labyrinth, handkerchief grab, push-in-the-corner, tick-tack-toe, jacks, hopscotch (snake, ten, dragging, multiple), duck duck goose and compass affect the visuality of the yard and enable children to have a good time by playing games. Also, they are good for the health of children since they replace passive computer games. In the study, a statistically significant difference could not be found between pretest and posttest by the total score related to the playgrounds drawn in the school yard. This can be attributed to bad weather, which prevented the completion of the drawings as planned and thus, children could not go out and play their games in the school yards. However, increases were observed in the pretest and posttest averages. It might be thought that this result could have been better if the children had had enough opportunity for playing games.

Positive differences were detected in some items of the questionnaire. Statistical differences were found between pretest and posttest for the item expressing that "students feel happy when they are playing games in the school yard and playgrounds". Akandere (2003) states that children both have fun and learn during playing games, and games, which affect all development areas of children, also function as a mirror reflecting their inner worlds and as a tool of communication with the adults.

A statistically significant difference was found between pretest and posttest for the item related to the frequency of students to play games in the school yard. According to Arnas (2004), children learn basic social rules such as cooperation, sharing, forming positive relations, respecting other people's rights and undertaking responsibilities during games they play with their friends. Children develop during games and grow with games. This is not a process but development itself. As a tool for children to learn the life, games are of great importance in terms of physical, emotional, social, mental and language development.

According to Malone and Tranter (2003), school yards should be arranged in a manner to accommodate various games and activities, to enable children to take spontaneous and free actions and to support learning and physical, cognitive and social development in children. In the present study, statistically significant differences were detected between pretest and posttest in the questions related to the impact of cleanliness and tidiness and visual features of the school yard when playing games. Tandoğan (2016) points out to the necessity of properly arranged school yards where children can play among the essential factors and features of primary school yards in the study about liveable school yards. Karadağ et al. (2012) detected certain deficiencies while evaluating playgrounds, use of yards and adequacy of playgrounds and equipment while Kaya and Kaya (2014) argues that lack of playgrounds is the main problem in the schools.

Zaks et al. (2001) state that energetic physical activities that students are involved at break times in the playgrounds of the school yards enable them to be more active physically and mentally during the courses while Gömleksiz and Özdaş (2013) argue that games affect working skills positively and increase school attachment levels. In the present study, low-level statistically significant difference was found between pretest and posttest of the school attachment scale. Blum (2005) argues that seven features positively affect school attachment levels of students and they include having a sense of belonging to the school, liking the school, perceiving teachers as supportive and caring, having good friends in school, having support for the present and future academic success, believing in the effectiveness and fairness of the discipline in the school, participation in extracurricular activities. These features are considered to be important for academic success. When the results of the present study are considered, positive and strong statistically significant differences are seen among pretest and posttests of the items "I love my school", "I am proud of being in this school", "I have friends that I like in the school", "If I had poor performance in my courses, my teachers would deal with it". In the other items related to the friends and teachers, in which statistically significant differences were not found, it was observed that the averages increased. This shows that children like their school, teachers and friends and they have positive opinions for the school. 
A statistically significant difference was found between pretest results and grades in the playgrounds questionnaire. This difference results from the $3^{\text {rd }}$ grade students. Younger children were impressed by the drawings in the playgrounds and playing in these areas much more than the others. However, pretest and posttest results of the school attachment scale did not differ significantly by sex, age and grade. Bellici (2015) found out that the school attachment levels of female secondary school students were higher than the male students. It was determined that school attachment levels decreased as the age and grade of students increased. It was also determined that school attachment levels of the students with higher academic success levels were higher than those with lower academic success levels. Karaşar and Kapçı (2006) stated that academic success was not a predictor for school attachment. However, school attachment was found as a predictor for fewer emotional problems. Lastly, attachment to friends predicted fewer peer problems, emotional problems and social behaviour problems.

At the end of this study, it was determined that the playgrounds drawn in the school yards slightly affected the school attachment levels. With respect to the use of playgrounds, positive improvements were observed in such areas as leadership, conducting works with friends, overcoming shyness, socialisation, abidance to rules, self-confidence, motivation for courses and entertainment. These results support our problem and sub-problem statements.

Based on these findings, it can be argued that playgrounds positively affect development and school attachment levels of children.

Accordingly, recommendations of the present study are as follows:

- As per the initial plan, this study would be conducted in 10 primary schools located in İzmit district of Kocaeli but due to adverse weather conditions, playgrounds could not be drawn in the school yards and thus, the study was confined to 3 schools. This study can be repeated with higher numbers of schools and students.

- In this study, the students could find the opportunity of playing games for a limited time, 2 to 3 weeks. Collection of the final data after longer periods might yield better scientific results.

- For winter conditions, playgrounds should be drawn in the suitable areas and halls within the school to provide students with the opportunity of playing games.

- Organization of game festivals in schools can cause excitement and also enable a higher number of students to take part in garden games and be healthier by reducing their addiction to computer games.

- Permanence and diversity in the playground drawings will be useful in terms of the development of the children.
- In terms of visuality, drawing colourful figures on the walls as well as the grounds and a proper arrangement for the surrounding will be more impressive.

\section{REFERENCES}

[1] Akandere, M. (2013). Eğitici Okul Oyunları. Nobel Akademik Yayıncılık, ISBN: 9786051333748, Ankara

[2] Akkülah, A.T. (2008). Oyun Alanları Güvenlik Standartlarının Araştırılması ve Nenehatun Parkı Örneğinde İrdelenmesi. Yayımlanmamış Yüksek Lisans Tezi, Selçuk Üniversitesi, Fen Bilimleri Enstitüsü, Konya.

[3] Algan, H., Uslu, C. (2009). İlköğretim Okul Bahçelerinin Tasarlanmasına Paydaş Katılımı: Adana Örneği, Akdeniz Üniversitesi Ziraat Fakültesi Dergisi, 2009, 22(2), 129-140

[4] Arnas, A. Y. (2004). Çukurova Üniversitesi Eğitim Fakültesi Okul Öncesi Öğretmenliği Ana Bilim Dalı Öğretim Üyesi, Adana. https://www.trendun.com/cocuk-oyunla-buyur Erişim tarihi: 23.07.2017

[5] Bellici, N. (2015). Ortaokul Öğrencilerinde Okula Bağlanmanın Çeşitli Değişkenler Açısından İncelenmesi. Abant İzzet Baysal Üniversitesi Eğitim Fakültesi Dergisi, 15(1), 48-65

[6] Blum, R. (2005). School Connectedness: Improving The Lives of Students. Baltimore: Johns Hopkins Bloomberg School of Public Health.

http://cecp.air.org/download/MCMonographFINAL.pdf (12.04.2017)

[7] Cemalcilar, Z. (2010). Schools As Socialization Contexts: Understanding the İmpact of School Climate Factors on Students' Sense of School Belonging. Applied Psychology: An International Review, 59(2), 243-272

[8] Çeliker, H.D., Tokcan, A., Korkubilmez, S. (2015). Does Motivation Toward Science Learning Affect Scientific Creativity?. Mustafa Kemal University Journal of Social Sciences Institute, 12(30): 167-192, ISSN: 1304-429-X.

[9] Çoban, B., Nacar, E. (2015). Ortaokullarda Eğitsel Oyunlar. Nobel Yayınları, 3. Basım Yayın No: 1157 Eğitim No:247, Sh. 7, 41, 42, 46 İstanbul.

[10] Gömleksiz, M.N., Özdaş, F. (2013). Teachers' Views on the Effectiveness of Free Time Activities Course: A Qualitative Study. Frat University Lourrnal of Social Science, 23 (1): 105-188

[11] http://isikilkokulu.meb.k12.tr/meb_iys_dosyalar/05/03/708 776/dosyalar/2014_01/07042149 24105032 gelenekselocu koyunlariuyumlulukmodu.pdf. Erişim tarihi: 15.07.2017.

[12] Karadağ, A.A., Mutlu, S., Sayın, Ş. (2012). Okul Bahçelerinin Oyun Alanı Olarak Değeri: Düzce Kenti Örneği. Ormanc1lık Dergisi 8(2) (2012) 45-56.

[13] Karaşar, B., Kapçı, E.G. (2016). Lise Öğrencilerinde Okula Bağlanma ve Akademik Başarının Çeşitli Değişkenler Açısından İncelenmesi. Ankara Üniversitesi Eğitim Bilimleri Fakültesi Dergisi, 49(1): 21-42. 
[14] Kaya, S., Kaya, F. (2014). The Determination And Solution of The Problem About Not Having Children Playground in School with Cooperative Problem Solving Method. Anemon, Muş Alparslan Üniversitesi Sosyal Biilimler Dergisi ISSN: 2147-7655, 2(2): 189-209

[15] Külekçi, E. (2016). Üniversite Öğrencilerinin Sosyal Sorumluluk Temelli Liderlik Becerilerinin Geliștirilmesine Yönelik Deneysel Bir Çalışma. IJOESS International Journal of Eurasia Social Sciences, 7(22): 56-80

[16] Malone, K., \& Tranter, P. (2003). Children's Environmental Learning and The Use, Design and Management of Schoolgrounds. Children, Youth and Environments, 13(2), 87-137, ISSN 1546-2250

[17] Mengi, S. (2011). Ortaöğretim 10. Ve 11.Sınıf Öğrencilerinin Sosyal Destek Ve Özyeterlik Düzeylerinin Okula Bağlılıkları İle İlişsisi. Yayınlanmamış Yüksek Lisans Tezi, Sakarya Üniversitesi, Eğitim Bilimleri Enstitüsü, Sakarya

[18] Özdemir, A. (2011). Okul Bahçesi Peyzaj Tasarım Anlayıșındaki Değişim Ve $\mathrm{Bu}$ Değişimin Uygulamaya Yansımalarının Bartın Kenti Örneğinde İrdelenmesi, Bartın Orman Fakültesi Dergisi, 13(19): 41-51 Issn: 1302-0943 Eissn: 1308-5875

[19] Ozdemir, A., Yilmaz, O. (2008). Assessment of Outdoor School Environments and Physical Activity in Ankara's
Primary Schools. Journal of Environmental Psychology 28, P: $287-300$.

[20] Savi, F. (2011). School Attachment Scale for Children and Adolescents: The Study of Validity and Reliability. Elementary Education Online, 10(1), 80-90, 2011.

[21] Şişman, E.E., Gültürk, P. (2011). İlköğretim Okul Bahçelerinin Peysaj Planlama Ve Tasarım İlkeleri Açısından İncelenmesi;Tekirdağ Örneği. Journal of Tekirdag Agricultural Faculty, 8(11): 53-60

[22] Tandoğan, O. (2016). More Livable School Grounds for Children. MEGARON 2016;11(4):629-637 DOI: 10.5505/megaron.2016.92053

[23] T.C. Millî Eğitim Bakanlı̆̆ı, Çocuk Gelişsimi Ve Eğitimi Oyun Ve Hareket Etkinlikleri, Ankara, 2016.

[24] http://www.megep.meb.gov.tr/mte program modul/modull er/Oyun\%20ve\%20Hareket\%20Etkinlikleri.pdf Erişim Tarihi: 23.03.2017

[25] Türkan, E: E. (2009). Investigating Children Playgrounds in Balikesir. Master Thesis, Selçuk University, Institute of Science, Department of Landscape, Konya.

[26] Zask, A., van Beurden, E., Barnett, L., Brooks, L.O., \& Dietrich, U.C. (2001). Active School Playgrounds - Myth or Reality? Results of the "Move It Groove It" Project. Preventive Medicine, 33, 402-408. 